Секция 10. Фотонные кристаллы, микрорезонаторы и метаматериалы. Нанофотоника

\title{
Вклад процессов взаимодействия активной среды с собственными модами фотонного кристалла в люминесцентный отклик кремниевых структур с самоформирующимися наноостровками Ge(Si)
}

Степихова М.В. ${ }^{1}$, Яблонский А.Н. ${ }^{1}$, Дьяков С.А. ${ }^{2}$, Ермаков О.Е. ${ }^{3}$, Скороходов Е.В. ${ }^{1}$, Шалеев М.В. ${ }^{1}$, Сергеев С.М. ${ }^{1}$, Шенгуров Д.В. ${ }^{1}$, Гиппиус Н.А. ${ }^{2}$, Богданов А.А. ${ }^{3}$, Новиков А.В. ${ }^{1}$, Красильник 3.Ф. ${ }^{1}$

${ }^{1}$ ИФМ РАН, 603950, Нижний Новгород, ГСП-105

${ }^{2}$ Сколковский институт науки и технологий, 143005, Москва, ул. Нобеля, 3

${ }^{3}$ Университет ИТМО, 199034, Санкт-Петербург, Биржевая линия В.О., 14

DOI 10.34077/Semicond2019-396

В последнее время значительный интерес исследователей привлекают возможности контролируемого управления свойствами полупроводниковых материалов в низкоразмерных фотонных структурах [1], где большое внимание уделяется фотонным кристаллам (ФК) и низкоразмерным ФК резонаторам, позволяющим контролируемым образом изменять излучающие свойства полупроводников [2,3]. В этой работе рассмотрены особенности люминесцентных процессов, наблюдаемых в фотонных кристаллах, сформированных на кремниевых структурах с наноостровками $\mathrm{Ge}(\mathrm{Si})$, излучающих в диапазоне длин волн $1.2-1.6$ мкм. Рассматриваемые структуры представляют интерес с точки зрения возможностей создания на их основе эффективных источников излучения для схем кремниевой нанофотоники.

Фотонные кристаллы с периодом решетки (a) от 350 до 1000 нм формировались методами электронно-лучевой литографии и плазмохимического травления на многослойных структурах, с 5-ю слоями наноостровков $\mathrm{Ge}(\mathrm{Si})$, выращенных на подложках SOI. Фактор заполнения ФК определялся соотношением радиуса отверстий $(r)$ к периоду решетки $r / a=0.2 \div 0.4$. Экспериментальные исследования полученных структур выполнялись методом микро-ФЛ в стандартной геометрии нормального падения возбуждающего и детектируемого лучей, получены результаты исследований диаграмм направленности излучения ФК со сканированием по углам в выделенных Г-М и Г-К направлениях зоны Бриллюэна ФК, исследованы поляризационные особенности излучения ФК.

В рамках проведенных исследований показано, что при значительных периодах решетки ФК (более 500 нм) в исследованных структурах имеет место усиление (вплоть до двух порядков величины) сигнала ФЛ наноостровков $\mathrm{Ge}(\mathrm{Si})$ на собственных модах ФК, локализованных в Г точке зоны Бриллюэна. Полученные результаты теоретических исследований показывают, что в исследуемых структурах имеют место явления усиления сигнала ФЛ на радиационных модах ФК и связанных состояниях в континууме (bound states in the continuum [4]). В последнем случае наблюдаемые резонансные спектры сигнала ФЛ характеризуются предельно тонкой структурой линий, добротность которых превышает $10^{3}$. Особенности излучающих свойств ФК в условиях взаимодействия активной среды с радиационными модами ФК и связанными состояниями в континууме прослеживаются в исследованных диаграммах направленности излучения ФК, отражающих особенности модовой структуры ФК в зоне Бриллюэна.

Исследование выполнено за счет гранта Российского научного фонда (проект № 19-72-10011).

[1] I. Staude, J. Schilling, Nature Photon., 11, 274 (2017).

[2] S. Wu, et al., Adv. Mater., 30, 1803362 (2018).

[3] S. Noda, M. Fujita, T. Asano, Nature Photon., 1, 449 (2007).

[4] C.W. Hsu, et al. Nat. Rev. Mater., 1, 1 (2016). 